\title{
Partner Notification for Gonorrhea and Syphilis in Belgrade
}

\author{
Milan BJEKIĆ ${ }^{1}$ and Hristina VLAJINAC ${ }^{2}$ \\ ${ }^{1}$ City Institute for Skin and Venereal Diseases, Belgrade, Serbia \\ ${ }^{2}$ Institute of Epidemiology, School of Medicine, University of Belgrade, Belgrade, Serbia \\ *Correspondence: Milan Bjekić, City Institute for Skin and Venereal Diseases, Džordža Vašingtona 17, Belgrade 11000, \\ Serbia, E-mail: milinkovski@gmail.com
}

UDC 616.972/.973-084(497.11 Belgrade)

\begin{abstract}
"Contact tracing" or "partner notification" refers to clinicians' efforts to identify sex partners of infected persons to ensure their medical evaluation and treatment. For many years partner notification has been a cornerstone in the management of patients diagnosed with sexually transmitted infections (STIs) and it is the essential component in the control of these infections. Clinicians' efforts to ensure the treatment of a patient's sex partners can reduce the risk for re-infection and potentially diminish transmission of STIs. Partner notification includes three different approaches for notifying the sexual partners of the person infected with a STI: provider referral, patient referral, and contract referral. The aim of our study was to evaluate the efficacy of partner notification among syphilis and gonorrhea cases registered at the City Institute for Skin and Venereal Diseases in Belgrade in 2016, and its contribution to prevention and control of these diseases. A retrospective chart review of patients with gonorrhea and early syphilis registered in 2016 was undertaken. We analyzed data about the possible source of infection as well as sexual orientation, provided on the official form for notification of syphilis and gonorrhea. The study included 112 male patients, 67 with gonorrhea and 45 with syphilis. Out of three modalities of partner notification offered to patients, only patient notification of sexual partner/s was accepted. Although all patients accepted this type of partner notification, index patients with gonorrhea notified only 17 partners (25.4\%) and index patients with syphilis also notified 17 partners (37.8\%). The effectiveness of partner notification for gonorrhea and syphilis cases was only $30.4 \%$, and its contribution to prevention and control of these diseases was lower than we expected. National guidelines offering standardized protocols for partner notification service provision can improve this process, as a novel approach with non-traditional method of partner notification such as patient-delivered partner therapy.

Key words: Contact Tracing; Sexual Partners; Gonorrhea; Syphilis; Sexually Transmitted Diseases
\end{abstract}

\section{Introduction}

Sexually transmitted infections (STIs) are a major public health problem due to the high incidence of acute infections, and the frequency and severeness of complications, particularly in women. In 2012, there were an estimated 357 million new infections (nearly one million per day) with one of four curable STIs - chlamydia, gonorrhea, syphilis and trichomoniasis (1).

Gonorrhea and syphilis are common bacterial venereal diseases and their reporting is mandatory in Serbia. During the period 2010 -2016 , the incidence of syphilis increased in Belgrade by $227.5 \%$, from 2.25 per 100,000 in 2010 to 5.12 per 100,000 in 2016, while the incidence of gonorrhea increased by $162.5 \%$, from 2.56 per 100,000 in 2010 to 4.16 per 100,000 in 2016 (2).
Prevention and control of STIs is based on the following five major strategies: education and counselling of persons at risk in order to avoid venereal diseases through changes of sexual behaviours and use of recommended prevention services; pre-exposure vaccination of persons at risk for vaccine-preventable STIs; identification of asymptomatic infected persons and symptomatic persons unlikely to seek health care; effective diagnosis, treatment and counselling of infected patients and evaluation, treatment and counselling of sex partners of patients infected with a STI (3).

The last one, known as "contact tracing" or "partner notification", refers to efforts of clinicians to identify sex partners of infected persons (index patients) to ensure their medical evaluation and treatment. For many years, 
partner notification has been a cornerstone in the management of patients diagnosed with STIs, and is considered an essential component in the control of these infections. Clinicians' efforts to ensure the treatment of patient's sex partners can reduce re-infection risks and potentially diminish transmission of STIs (4).

Partner notification includes three different approaches to notify the sexual partners of a person infected with an STI (5): provider referral, patient referral and contract referral. Provider referral means that healthcare professionals elicit information from index patients about their sexual contacts, notify these contacts about possibly being at risk of acquiring a STI, and recommend screening and treatment for such infection. Clinicians inform the partner confidentially, without disclosing the identity of the index patient. This is a method of choice when an individual fears a violent reaction (6).

Patient referral involves patients notifying their sexual partners. Various methods of partner notification can be provided by an index patient such as verbal contact (face to face), telephone or email communication, and notification card delivery to sexual partners. Contact referral is an approach when the index patient agrees to notify his partner(s) within a specified time period and if this is not done, the health adviser will proceed to provider referral. However, the stigma attached to venereal diseases makes partner notification difficult (7).

Partner notification actions in the case of index patients with syphilis, gonorrhea, chlamydia and HIV in most European countries are priorities and the main responsibility of specialty health providers from reference clinics (5).

Partner notification was probably practiced for many years before it became formally introduced as a means of STIs control in different countries around the world. In Britain and Sweden, partner notification for venereal diseases has been practiced since the $19^{\text {th }}$ century $(8,9)$, while in the US contact tracing had become a central feature of syphilis control programs by the 1940s (10).

There are various processes to measure partner notification efficacy such as the number of contacts notified, the number of contacts presented for screening, the number of contacts identified who tested positive, and the number of contacts treated for a STI (11).

The aim of our study was to measure the efficacy of partner notification among syphilis and gonorrhea cases registered at our institution in 2016 and its contribution to prevention and control of these diseases.

\section{Material and Methods}

A retrospective chart review of patients with gonorrhea and early syphilis (primary, secondary and early latent syphilis) registered in 2016 was undertaken at the City Institute for Skin and Venereal Disease in Belgrade. Data about the possible source of infection as well as sexual orientation, provided on the official syphilis and gonorrhoea notification form were analyzed.

Case definitions of gonorrhea and early syphilis were in line with STD Surveillance case definitions (12). To diagnose early syphilis, Venereal Disease Research Laboratory (VDRL) and Treponema pallidum hemagglutination assay (TPHA) tests were used. To diagnose gonorrhea, standard laboratory examination was done, i.e. microscopy, while inoculation on culture media was technically limited.

One dermatologist interviewed all patients and gave them detailed explanations about the importance of referring their sexual contacts for screening and treatment, because they were unaware of infection and its serious reproductive and general health consequences. In order to identify other persons at risk, the infected patients were asked to refer their sexual partners in the last two months for gonorrhea cases. The infectious period for syphilis was estimated based on the syphilis stage: 3 months plus duration of symptoms for primary syphilis, 6 months plus duration of symptoms for secondary syphilis, and 1 year before the diagnosis for early latent syphilis. The patients were offered all three modalities of partner notification by their dermatologist.

The research was approved by the Ethics Committee of the City Institute for Skin and Venereal Diseases in Belgrade. Data are presented by counts and percentages, while data analysis was based on proportions and $\chi^{2}$ test and Fisher exact probability test. 
Table 1. Number of notified sexual partners by patient referral

\begin{tabular}{lcc} 
Sexually transmitted disease & Number of index patients & $\begin{array}{c}\text { Number (\%) of notified } \\
\text { sexual partners }\end{array}$ \\
Gonorrhea & 67 & $17(25.4)^{\star}$ \\
\hline Syphilis & 45 & $17(37.8)$ \\
\hline Total & 112 & $34(30.4)$ \\
\hline
\end{tabular}

* 11 index patients notified one sexual partner and 3 index cases notified two partners

\section{Results}

The study included 112 male patients, 67 with gonorrhea and 45 with syphilis. Out of the three partner notification modalities offered, only patient notification of sexual partner/s was accepted. Index patients with gonorrhea notified 17 partners (25.4\%), as well as index patients with syphilis who notified 17 partners (37.8\%) (Table 1). The difference was not statistically significant.

Out of 112 index patients, 63 were heterosexual and 49 were homosexual. Gonorrhea was more frequent among heterosexual men $(82.5 \%)$ and syphilis among homosexual men $(69.4 \%)$. In the group of patients with gonorrhea, homosexuals notified their sexual partner/s significantly more frequently than heterosexuals $(p<0.05)$. In contrast, among patients with syphilis, heterosexuals notified their partner/s more frequently than homosexuals, but the difference was not significant (Table 2).

All notified patients were asymptomatic and all of them were adequately treated.

Syphilis was diagnosed by positive serological tests. When it comes to gonorrhea, the diagnosis through inoculation on culture me- dia was technically limited and sexual partners were treated in the same way as contacts.

\section{Discussion}

Partner notification is the process of contacting sexual partners of a person with a STI and informing them that they have been exposed to infection. They are then offered screening and treatment if indicated. The aim is to find and treat an undiagnosed, often asymptomatic infection and shorten the average period of infectiousness, thus reducing transmission of the infection. Partner notification should be undertaken for all those with treatable STIs (gonorrhea, chlamydia, syphilis, trichomoniasis, and chancroid) including hepatitis B and HIV (13).

The most commonly used method for partner notification is patient referral, whereby the index case has a responsibility to inform his sex partner/s about their exposure to a STI. Patient referral is the preferred approach, partly because most patients prefer to notify their own partners than to give the physician their names, post and/or email address or telephone numbers, and also be-

Table 2. Number of sexual partners by sexual orientation notified by gonorrhea and syphilis index patients

\begin{tabular}{ccc} 
Sexual orientation & $\begin{array}{c}\text { Number of index patients } \\
\text { with gonorrhea }\end{array}$ & $\begin{array}{c}\text { Number (\%) of notified } \\
\text { sexual partners }\end{array}$ \\
Heterosexual & 52 & $10(19.2)$ \\
\hline Homosexual & 15 & $7(46.7)^{\star} \dagger$ \\
\hline Heterosexual & Number of index patients \\
with syphilis & $5(45.5)$ \\
\hline Homosexual & 11 & $12(35.3)$ \\
\hline
\end{tabular}

* 3 index patients notified one sexual partner and 2 index cases notified 2 partners; $† P<0.05$ for differences between heterosexual and homosexual men 
cause it may be the only option in non-specialist settings (14). The clinician has to discuss the importance of partner notification with index patients, explaining the information confidentiality process, the possibility of partners being infected and asymptomatic, the risks of re-infection and also the consequences of non-treatment. Providing resources such as STI fact sheets and partner notification cards and an individualized approach have been used successfully to enhance partner notification efforts (13).

Gorbach et al. (15) reported that up to $1 / 3$ of patients failed to inform all partners (especially casual and ex-partners) due to embarrassment or fear for personal safety and reputation. However, fear of partner reactions to the possibility of positive test results to a STI is associated with important obstacles for partner notification (16).

In our study, patient referral was the only accepted modality of partner notification. The only data that our index cases gave to the dermatologist were their sexual partners' names or gender and promise to inform or refer them to our Institution. The majority of their sexual partners were anonymous or untraceable. Moreover, some cases were reluctant to identify their partners, despite knowing the importance of informing them.

Patient referral effectiveness relies on index cases being willing or able to identify their sexual contacts, and finally, their notified contacts must be willing and able to access health services and require testing and treatment. According to our results, only $1 / 3$ of partners were notified $(25.4 \%$ for gonorrhea and $37.8 \%$ for syphilis). During an outbreak of early syphilis in Belgrade, $24.4 \%$ of cases were referred by their sexual partners (17). In the study by Reynolds et al., $19.9 \%$ of cases with syphilis were detected through partner notification (18). Another study has shown that the outcome of patient referral in gonorrhea and chlamydia infections was $20.5 \%$ (19). Low et al. (20) reported that in the United Kingdom, patient referral reached $40-60 \%$ of named sexual partners. One study showed that between $22 \%$ and $68 \%$ of men with gonorrhea were notified by partners who had an asymptomatic infection (21).

In our study, gonorrhea was more frequent among heterosexual men, and syphilis among homosexual men. This is in line with the fact that at the beginning of the new millennium, the incidence of syphilis has been on rise in Belgrade, occurring primarily among men who have sex with men (17).

In the group of patients with gonorrhea, homosexuals notified their sexual partners significantly more frequently than heterosexuals, while among patients with syphilis, heterosexuals notified their partners more frequently, but not significantly, than homosexuals.

Since 2008, counselling is provided at the Department for Sexually Transmitted Diseases of our Institution, and it is at disposal to patients without referral of their physicians. The Department is friendly to vulnerable population (homosexual men, patients who live with HIV). This fact partly explains better partner notification among gonorrhea cases in homosexual men. At the same time, in Serbia, traditionally, men with genital symptoms and venereal diseases visit dermatologists, while women prefer to visit their gynecologists, and even when our heterosexual patients referred their female partners, the notification failed. Owing to inadequate laboratory facilities (culture for endocervical, rectal and pharyngeal specimens), gynecologists cannot confirm the diagnosis of gonorrhea, and therefore women are not properly treated.

Early syphilis is always treated by a dermatologist. According to the data from the official partner notification form, our heterosexual syphilis cases notified their partners more frequently because they were their regular partners, while a predominant barrier to notification in homosexual men was engagement with anonymous sexual partners.

Over the last decade, several non-traditional methods have been developed to facilitate the notification process. In patientdelivered partner therapy, gonorrhea- and chlamydia-positive patients are provided with prescriptions or medications to be directly given to their sexual partners (22). Other methods involve anonymous notification via email, text messaging or electronic postcards (23).

\section{Conclusion}

In summary, under the present study, effectiveness of partner notification for gonorrhea and syphilis cases was only $30.4 \%$, and its contribution to prevention and control of these diseases was lower than expected. Cur- 
rently, our country has no national guidelines offering standardized protocols for partner notification service provision which could enhance this process. Provider referral can be more effective, especially for patients who are wary of informing partners themselves. A nontraditional method of patient-delivered partner therapy may improve partner notification. We should also provide more sensitive diagnostic tests for gonorrhea, such as Nucleic Acid Amplification Tests, and change testing policies including testing at multiple anatomical sites (e.g. rectum, pharynx). Coordinated and efficient surveillance, partner services, screening of population at-risk and their education, as well as early diagnosis and treatment could diminish transmission and consequences of these diseases.

\section{Abbreviations \\ STIs - sexually transmitted infections oratory VDRL - Venereal Disease Research Lab- TPHA - Treponema pallidum hemagglu- tination assay}

\section{Acknowledgement}

This paper was supported by the Ministry for Science and Technology of Serbia, through Contract No. 175042 (2011 - 2014).

\section{References}

1. Newman L, Rowley J, Vander Hoorn S, Wijesooriya NS, Unemo M, Low N, et al. Global estimates of the prevalence and incidence of four curable sexually transmitted infections in 2012 based on systematic review and global reporting. PLoS One. 2015;10(12):e0143304.

2. Center for Disease Control and Prevention: Report of infectious diseases in Belgrade in 2016. Belgrade: City Institute of Public Health of Belgrade; 2017. p. 51.

3. Workowski KA, Bolan GA, Centers for Disease Control and Prevention. Sexually transmitted diseases treatment guidelines, 2015. MMWR Recomm Rep. 2015;64(RR-03):1-137.

4. Trelle S, Shang A, Nartey L, Cassell JA, Low N. Improved effectiveness of partner notification for patient with sexually transmitted infections: systematic review. BMJ. 2007;334(7589):354.

5. European Centre for Disease Prevention and Control. Public health benefits of partner notifications for sexually transmitted infections and HIV. Stockholm: ECDC; 2013.
6. Desir FA, Ladd JH, Gaydos CA. Survey of partner notification for sexually transmissible infections in the United States. Sex Health. 2016;13(3):162-9.

7. Low N, Broutet N, Adu-Sarkodie Y, Barton P, Hossein M, Hawkes S. Global control of sexually transmitted infections. Lancet. 2006;368(9551):2001-16.

8. Adler MW. The terrible peril: a historical perspective on the venereal diseases. $\mathrm{Br}$ Med J. 1980;281(6234):206-11.

9. Ruden AK, Jonsson A, Lidbrink P, Allebeck P, Bygdeman SM. Endemic versus non-endemic gonorrhoea in Stockholm: results of contact tracing. Int J STD AIDS. 1993;4(5):284-92.

10. Brandt AM. No magic bullet-a social history of venereal disease in the United States since 1880. Expended edition. New York: Oxford University Press; 1987.

11. Cowan FM, French R, Johnson AM. The role and effectiveness of partner notification in STD control: a review. Genitourin Med. 1996;72(4):247-52.

12. Centers for Disease Control and Prevention (CDC). STD surveillance case definitions. [cited 2017 Aug 20]. Available from: http://www.cdc.gov/std/stats/casedefinitions-2014.pdf.

13. Hogben M. Partner notification for sexually transmitted diseases. Clin Infect Dis. 2007;44 Suppl 3:S160-74.

14. Apoola A, Radcliffe K, Das S, Robshaw V, Gilleran G, Kumari BS, et al. Patient preferences for partner notification. Sex Transm Infect. 2006;82(4):327-9.

15. Gorbach PM, Aral SO, Celum S, Stoner BP, Whittington WL, Galea J, et al. To notify or not to notify: STD patients' perspectives of partner notification in Seattle. Sex Transm Dis. 2000;27(4):193-200.

16. Alam N, Chamot E, Vermund SH, Streatfield K, Kristensen S. Partner notification for sexually transmitted infections in developing countries: a systematic review. BMC Public Health. 2010;10:19.

17. Bjekić $M$, Šipetić $S$. An outbreak of early syphilis in patients registred at City Institute for Skin and Venereal Diseases in Belgrade from 2010 to 2012: a case series of 86 patients. Serbian Journal of Dermatology and Venerology. 2013;5(2):65-71.

18. Reynolds SL, Kapadia AS, Leonard L. Ross MW. Examining the direct coost and effectiveness of syphilis detection by selective screening and partner notification. J Pub Health Med. 2001;23(3):339-45.

19. van Duynhoven YT, Schop WA, van der Meijden WI, van de Laar MJ. Patient referral outcome in gonorrhoea and chlamydial infections. Sex Transm Inf. 1998;74(5):323-30.

20. Low N, Welch K, Radcliffe K. Developing national outcome standards for the management of gonorrhoea and genital chlamydia in genitourinary medicine clinics. Sex Transm Infect. 2004;80(3):223-9.

21. Klann JG, Mendis M, Phillips LC, Goodson AB, Rocha $\mathrm{BH}$, Goldberg HS, et al. Taking adventage of continuity of care documents to populate a research repository. J Am Med Inform Assoc. 2015;22(2):370-9.

22. Golden MR, Hughes JP, Brewer DD, Holmes KK, Whittington WL, Hogben M, et al. Evaluation of a population 
based program of expedited partner therapy for gonorrhoea and chlamydial infection. Sex Transm Dis. 2007;34(8):598-603.

23. Kerani RP, Fleming M, Golden MR. Acceptability and intention to seek medical care after hypothetical re- ceipt of patient-delivered partner therapy or electronic partner notification postcard among men who have sex with men: the partner's perspective. Sex Transm Dis. 2013;40(2):179-85.

\section{Kontaktiranje partnera osoba obolelih od gonoreje i sifilisa u Beogradu}

\section{Sažetak}

Notifikacija partnera predstavlja identifikaciju seksualnih partnera osoba obolelih od polnih bolesti radi njihovog medicinskog ispitivanja i lečenja. Godinama predstavlja značajnu kariku u kontroli širenja i prevenciji polnih bolesti. Napori zdravstvenih radnika da obezbede tretman i partnerima obolelih od polnih infekcija, mogu sprečiti rizik nastanka reinfekcije i uticati na smanjenje daljeg širenja infekcije u populaciji. Postoje tri načina notifikacije partnera: partnera obaveštava zdravstveni radnik, oboleli pacijent i postoji takozvano ugovorno obaveštavanje. Cilj našeg istraživanja bio je da utvrdimo efikasnost notifikacije partnera pacijenata obolelih od gonoreje i ranog sifilisa koji su registrovani u Gradskom zavodu za kožne i venerične bolesti u Beogradu tokom 2016. godine i doprinos notifikacije u prevenciji i kontroli širenja ovih oboljenja. Analizirani su podaci prikupljeni iz zdravstvenih kartona obolelih, kao i podaci iz notifikacionih lista o njihovoj seksualnoj orijentaciji i izvoru infekcije. U istraživanje je uključeno 112 muškaraca, 67 sa dijagnostikovanom gonorejom i 45 sa dijagnostikovanim sifilisom. Svi oboleli su prihvatili da sami obaveste svoje partnere ali su i oboleli od gonoreje i oboleli od sifilisa notifikovali samo po 17 partnera $(25,4 \%$, odnosno $37,8 \%)$. Efikasnost notifikacije partnera obolelih od gonoreje i sifilisa bila je ukupno $30,4 \%$ i njen doprinos kontroli širenja ovih bolesti je manji nego što smo očekivali. Nacionalni vodiči sa standardizovanim protokolima značajno bi poboljšali proces notifikacije partnera kao i usvajanje novih netradicionalnih metoda notifikacije kao što je podela terapije seksualnim partnerima od strane obolelog pacijenta.

Ključne reči: Kontaktiranje partnera; Seksualni partneri; Gonoreja; Sifilis; Seksualno prenosive bolesti 